\title{
Analysis on New Approaches of Ideological and Political Education in Colleges under New Media Environment
}

\author{
Liping Zhang \\ College of Elementary Education, China West Normal University, Nanchong, China \\ Email: liping@sina.com
}

Received 29 November 2015; accepted 26 December 2015; published 29 December 2015

Copyright (C) 2015 by authors and Scientific Research Publishing Inc.

This work is licensed under the Creative Commons Attribution International License (CC BY). http://creativecommons.org/licenses/by/4.0/

(c) (i) Open Access

\begin{abstract}
The increasing rise and development of new media technology has influenced the college students profoundly. And new media technologies with remarkable importance such as Wechat, $Q Q$ and MicroBlog have given great impacts on current ideological and political education in colleges. Current ideological and political education in colleges is facing new requirements under new media environment, and the performance of ideological and political education in colleges is facing new development conditions as well. On one hand, the effective utilization of new media has significantly shrunk the gap between college teaching staffs and students, rendering convenience to the ideological and political education in colleges. On the other hand, due to the great openness of new media, it has influenced the authority of ideological and political work in colleges to some extent, and it may also influence the leading capacity of the working staff of ideological and political education in colleges, which has weakened the educational achievements to a large extent. Currently, how to utilize the new media environment effectively to make it beneficial to the ideological and political education in colleges has been a problem needed to be settled urgently. This paper has mainly analyzed current situation of the existing ideological and political education in colleges, and has studied on the method of ideological and political education in colleges under new media environment, thus we put forward new approaches for the ideological and political education in colleges.
\end{abstract}

\section{Keywords}

New Media, Environment, Colleges, Ideological and Political Education in Colleges, New Approaches 


\section{Introduction}

The development of technology has made computer become an indispensable tool for communication and work for modern people, and has made the new media with computer as its remarkable representative to be known, concerned and used by more and more young people. The traditional teaching mode has been changed significantly by online teaching and online communication. New media has occupied the education field rapidly, and has integrated in the daily life of tens of thousands students, influencing students' thinking mode at any time and changing their cognition degree on education and teaching. Meanwhile, the development of new media has brought about opportunities and challenges to the ideological and political education in colleges. The emphasis and problem of ideological and political education in colleges under existing mode lies in how to utilize new media tools reasonably to adapt to the changing new media environment better, and to study the more scientific approaches to cope with the challenges brought by new media environment to the ideological and political education in colleges (Liu, 2004).

\section{Overview of New Media}

\subsection{Definition of New Media}

So far, new media has been defined in broad sense as: The intermediate species in body shape within impression emerged on the basis of computer processing technique. However, the new and old are by comparative speaking. The reason why it is called new media is that it is a technological means relies on digital times to provide digital services to the public, such as digital television, newspaper, magazine, radio, etc.

\subsection{Characteristics of New Media Technology}

In comparison with traditional media, new media is established on the basis of traditional media. It mainly takes advantages of such modern technology as digital technique and network technique, with the following characteristics:

1) Universality: Under the new media environment, government and media organization are not the only information source, yet everyone becomes a spreader or receiver of the information. The communication subject has become increasingly extensive, and a mass communication age has arrived.

2) Interactivity: Real time communication and interaction can be realized under new media environment, and all users can participate to express their own ideas and opinions freely, which has greatly enhanced the receiver's positivity, and made the full participation mode to be realized;

3) Timeliness: One message can be transmitted all over the world within just a second via such new media approaches as internet. It can transmit not only words and sounds, but also the videos, which has broken through the limitation of time and space with strong timeliness;

4) Richness: New media covers not only the pictures and words within the scope of traditional media, but also such novel information types as video and audio. It contains plentiful contents with a wide range;

5) Virtuality: Various messages and comments can be uploaded and expressed at will through Internet and Mobile Phone Client. And it has unparallel advantage in terms of transmitting speed by comparison with traditional media. However, this speedy and effective message transmitting mode has brought us enormous temptation while bring us great convenience. There is certain virtuality in internet media with rapid development. From the original Forum, Post Bar to QQ, and to MicroBlog and Wechat, various information can be forged in the virtual environment of Internet, which has no way to verify, increasing the possibility of virtual information generation, weakening the government's control, adding difficult to direction of public opinion.

\section{Current Situation of Ideological and Political Education in Colleges}

Ideological and political education in colleges has always been at the important position. Accompanying with the booming development of new media industry, network information can be seen everywhere (Xu, 2014). In addition, modern college students have the characteristics of pursuing of independence, treason, rebellion, strong curiosity and complicated thought, which has increased difficulty in the ideological and political education in colleges. And many problems also exist in the specific education.

1) Passive Position of Students: Different from the general specialized courses, ideological and political edu- 
cation stresses shaping of ideal personality and cultivation of good moral trait of the college students, which lays particular emphasis on environmental infection, and its effectiveness cannot be evaluated within a short period. However, in specific education activities, the burden of ideological and political education has fallen on the head teacher and instructor, rendering it cannot be integrated into other class activities effectively, and lacking of the consideration of student subjectivity. Under such educational mode, students have become a tool for the teacher to finish teaching tasks, and the goal of personality shaping and moral trait cultivation cannot be realized.

2) Paying attention to knowledge accumulation: With the long-term impact of exam education, society, parents and schools pay too much attention to students' academic performance. This problem also exists in the ideological and political work. They only care about the accumulation of theoretical knowledge in the ideological and political work. We carry out the ideological and political work through preaching or teaching, and check the ideological and political achievement through written examination. Students study ideological and political content through reciting and exercise training. This ideological and political education mode pays too much attention to theoretical knowledge, and ignores actual situation, which seriously depart from the ideological and political target in new media environment. It does not accord with the characteristics of the modern college students. The final result is not very good. There are often fights, disturbances and someone jumping from building in campus. For colleges and universities, the classroom teaching is an important way to carry out the ideological and political education. However, in the actual classroom teaching, teachers only teach students according to textbooks and rarely introduce practical cases. Teachers only ask students underline the key points and students memorize them mechanically in order to cope with exams. Though students may gain good results, they may forget soon.

\section{The New Media Environment Has Provided Opportunities for Ideological and Political Education in Colleges and Universities}

\subsection{The New Media Environment Has Greatly Enriched the Means of Ideological and Political Education in Colleges and Universities}

Under the new media environment, we can use more methods and means in the ideological and political education in colleges and universities compared with traditional education mode. As is known to all, teachers have to talk with students face to face in tradition environment, which has become the premise and necessary condition for the smooth development of the ideological and political education in colleges and universities under the traditional environment (Zhang \& Yu, 2012). It seriously limits the means of ideological and political education in colleges and universities. On the one hand, the meeting of students and teachers may increase time burden in teaching. On the other hand, the face-to-face conversation can bring both students and teachers some pressure and greatly reduce the effect of education. In the new media environment, the teacher can use QQ, Wechat and other chat tools to communicate with students, and students can receive the ideological and political education in front of a computer.

\subsection{The New Media Environment Enables Us to Carry out More Flexible Ideological and Political Education in Colleges and Universities}

In traditional ideological and political education, teachers in colleges and universities often need to spend a lot of time to understand the students' psychological changes. After they have mastered the basic situation of the students' thinking, they could carry out the ideological and political education. It, to some extent, has restricted the effect of ideological and political education. The work is stranded, and teachers could not correct the students' ideas in time. Contrary to the traditional ideological and political education, the ideological and political education in the new media environment can pay close attention to the students' ideological state. For example, a student may publish a passive mood in the QQ space and the instructor finds it through browsing space, and then the instructor could communicate with the students and give students appropriate comfort and guidance according to the student's actual situation, help the student adjust his/her mental state, and improve the flexibility of ideological and political education in colleges and universities (Liu, 2014).

\subsection{The New Media Has Effectively Promoted the Development of Contemporary College Students}

The symbol of the modernization of ideological and political education in colleges and universities is the wide 
application of new media technology. The organic combination of ideological and political education and the technology has improved the sharing of resources and the interactivity of education and opened the traditional education environment, greatly improving the efficiency of ideological and political education. With network information technology as basic characteristic, the new media have changed the way of communication of the contemporary college students imperceptibly, which enables the students to communicate across the world. College students are not rich in social practice and narrow in social communication, and their communication objects are usually students and teachers. The new media not only remove the shackles of the traditional communication of college students, but also greatly improve their social enthusiasm. They have the opportunity to understand the culture and customs of different countries and nations. New media have greatly broadened their horizons and enriched their experience. In addition, students' social layers are gradually expanded through information receiving and transmission in exchange, which could increase the effectiveness of ideological and political education (Liu, 2015).

\subsection{The New Media Has Enriched the Ideological and Political Education Resources}

The ideological and political education resources mainly refer to all elements that can be developed and used by educators, and are conducive to the realization of ideological and political education target. New media also belong to the ideological and political education resources. The birth of new media is the crystallization of the development of science and technology. Science and technology are still developing and progressing in a fast pace. In addition, on the basis of the Internet, the application of new media is becoming increasingly widespread. All organizations and individuals can use this technology to provide a way for its own development. Of course, based on different purposes, the effects of the new media are also not the same. Some people use new media to increase their knowledge, enrich their knowledge, and improve their comprehensive quality. But some use new media to spread negative or reactionary information, which harms the society. New media bears the important mission of providing ideological and political education resources. The picture, text, voice and image of new media can provide students necessary ideological and political education information. Without correct ideological and political education resources, it is difficult to effectively achieve educational goals and unable to create a good ideological and political education environment. Let alone the evaluation and feedback of ideological and political education information. Even it may lead to the paralysis of ideological and political education work in colleges and universities.

\section{The Means and Methods Are Used to Improve the Efficiency of Ideological and Political Education in Colleges and Universities under New Media Environment}

\subsection{Make Full Use of New Media Technology to Expand Self Platform}

The present new media environment requires the educational administration personnel to have a strong new media consciousness, and master the superb new media technology, and make use of new media technology, so that it may serve for the ideological and political education in colleges and universities. In view of this, colleges and universities should strengthen the construction of new media facilities and construct own campus website platform, so as to widespread new media ideas. By systematic analysis of the advantages and disadvantages of the new media on education, colleges and universities could give full play to the advantages of new media, make up for the shortcomings of the ideological and political education and expand the ideological and political education platform.

\subsection{Make up and Supplement College Students' Cognitive Level of New Media}

New media environment has provided diverse multimedia information for students. If students lack cognition degree, this kind of information will confuse them and contort their political thoughts. At the present stage, ideological and political educators in colleges should pay attention to training students' cognition degree of new media, make students have strong discrimination ability, screen new media information that is adverse to them, and then develop good ideological and political feelings.

\subsection{Optimize Ideological and Political Educational Management System}

With the booming development of new media industry, students' thoughts are more diversified, ideological and 
political education in school also faces great challenges. In order to further complete the work of ideological and political education in colleges, it needs joint efforts of teachers and students. It has become the key problem faced by educators in colleges that how to make use of new media means to improve the quality of ideological and political education work. To effectively solve this problem, educators in colleges should strengthen the exploration, and the ideological and political educational management system is the important guarantee for the smooth development of ideological and political education work. Therefore, we should establish reasonable ideological and political educational management system and feasible supervision mechanism.

1) Establish reasonable management system

Ideological and political educators in colleges should carry out various management works according to management system, strengthen communication and coordination between other departments, jointly promote the work of ideological and political education, ensure clear division of labor and responsibilities, correctly guide public opinions in colleges, organize diverse cultural activities to enrich college students' school life and continuously promote ideological and political culture. Meanwhile, they should also encourage staff related to ideological and political education to actively learn new media technology and master students' learning dynamic with the help of new media technology.

2) Establish feasible supervision mechanism

The establishment of supervision mechanism includes the establishment of supervision team and supervisory system. When establishing supervision mechanism, educators should closely combine with conditions of themselves and strictly abide by the laws and regulations to effectively control the spread of negative information, compile reasonable information examination and approval system and adopt information filtering technology. Because the comprehensive quality of supervision team directly influences the final effects of ideological and political education work, under new media environment, it is necessary to strengthen the training strength of ideological and political education team and make educators have higher political culture and good moral trait and then better give play to the role of model in college students. Besides, educators in colleges should also realize that the optimization of network supervision mechanism has close relationship with advanced supervision technology. In the process of training and education, they should add capital investment, continuously strengthen network supervision technology and realize overall control.

\subsection{Use New Media to Renovate the Method of Ideological and Political Education}

Under new media environment, a large number of new media means spring up, traditional educational method of ideological and political education cannot meet the needs for increasingly diversified ideology and politics. Therefore, ideological and political teachers in colleges should realize the important promoting effects of new media in ideological and political education role. First of all, with the help of new media, teachers can establish real-time communication channel of two-way communication in colleges, let more students join in the team of ideological and political education, improve students' participation, which can help teachers to master students' situation and ideological and political needs more comprehensively, and then implement targeted ideological and political education work; secondly, in specific ideological and political education work, effectively use the method of value penetration, this is because the method of value penetration has certain penetration function. Besides, the new media has profound influence and strong function of value penetration. Through colorful cultural activities, it can integrate main values in ideological and political education into cultural activities in campus and make it leave a deep impression on students' mind and then promote the effects of ideological and political education in colleges and improve the quality of education; lastly, staff in ideological and political education should promote and implement practical teaching. In order to better implement this measure, ideological and political teachers should make use of new media resources such as the internet to positively collect teaching cases, and choose carefully, discuss with students together in specific classroom activities to consolidate and memorize theoretical knowledge. Meanwhile, they should also create more opportunities for students to experience outside the school, reasonably arrange extracurricular internship according to teaching contents, truly guarantee students' personal safety, which can largely arouse students' learning enthusiasm and help the effective establishment of ideological and political education class.

\section{Conclusion}

New media environment is a double-edged sword for the work of ideological and political education in colleges. 
It can create good working environment for ideological and political education work in colleges, at the same time it can bring certain difficulties and challenges. With continuous update of scientific and technical level, new media tools are bound to become necessary means of ideological and political education work in colleges. The problems that urgently need to be solved by the present ideological and political education in colleges include how to better adapt to the new media environment, use limited conditions to create better effects for ideological and political education in colleges; how to evade the conflicts between new media environment and ideological and political education in colleges at the same time timely adjust the working mode of ideological and political education, better serve the ideological and political education work. Only by improving these problems can ideological and political education in colleges to better serve college students and keep up with the pace of era development.

\section{References}

Liu, Y. (2004). Research on Means of Ideological and Political Education in Colleges under New Media Environment. Reading and Writing (Education and Teaching Periodical), 3, 80-85.

Liu, J. (2014). Research on Application of Ideological and Political Education in Colleges under New Media Environment. Journal of Knowledge Seeking, 11, 10-11.

Liu, X.H. (2015). Discussion on Research on Means of Ideological and Political Education in Colleges under New Media Environment. Technology Wind, 1, 22-27.

Xu, Z.X. (2014). Discussion on Means of Ideological and Political Education in Colleges under New Media Environment. Science and Technology Information, 20, 20-21.

Zhang, S., \& Yu, X. F. (2012). Implicit Education of Ideological and Political Work in Colleges under New Media Environment. Journal of Tongling College, 4, 80-82. 